\title{
Pancreatic A Cell Generates Action Potential
}

\author{
Masatoshi IKeUCHI and Kinji YAGI \\ Department of Physiology, Jichi Medical School, \\ Minamikawachi-machi, Tochigi, 329-04 Japan
}

\begin{abstract}
Summary Intracellular membrane potential recording was attempted with pancreatic endocrine cells in monolayer culture. Morphologically identified A cells produced spike action potentials in response to injected electric current. The action potential was also evoked in the sodiumfree medium. It was concluded that pancreatic A cells are electrically excitable and probably generate $\mathrm{Ca}$ spike.

Key Words: pancreatic A cell, Ca spike.
\end{abstract}

The pancreatic islet is known to contain three different kinds of endocrine cells: glucagon-producing A cells, insulin-producing B cells, and somatostatinproducing D cells. Pancreatic B cells in the isolated mouse islet have been demonstrated by DEAN and MATTHEWs (1968) to generate an action potential which is characterized by numerous spikes superposed on a depolarization plateau. However, it is yet unknown whether the A cell is also electrically excitable. Our previous study (KANAZAWA et al., 1976) has indicated that each of the A and B cells in monolayer culture can be identified morphologically under a phase contrast microscope. In the present study, intracellular recording of membrane potential was attempted in the A and B cells which were identified morphologically in the monolayer culture derived from the pancreas of neonatal rats in order to determine whether pancreatic A cells generate an action potential in response to injected current.

The pancreas excised from neonatal rats 4 or 5 days after birth was minced and digested in a phosphate-buffered saline containing trypsin $(0.2 \%)$ and collagenase $(0.01 \%)$. The isolated pancreatic cells thus obtained were cultured in medium 199 containing $10 \%(\mathrm{v} / \mathrm{v})$ of fetal calf serum, glucose $(300 \mathrm{mg} / \mathrm{dl})$ and penicillin $\mathrm{G}(400 \mathrm{IU} / \mathrm{ml})$ at $37^{\circ} \mathrm{C}$ in a $\mathrm{CO}_{2}$-incubator for 3 or 4 days. Adult rat pancreas was also used. Details of the culture technique are the same as those described earlier (LAMBERT et al., 1972; KAWAZU et al., 1977). Intracellular recording was done on the culture cells, usually in modified Locke's solution $\left(\mathrm{NaCl}, 154 ; \mathrm{KCl}, 5 ; \mathrm{CaCl}_{2}, 2.4 ; \mathrm{MgCl}_{2}, 1.3 ;\right.$ glucose, $5.5 \mathrm{in} \mathrm{mM}$; and at $\mathrm{pH}$ buffered

Received for publication July 9, 1982

池内正俊，八木欽治 
at 7.40 with $5 \mathrm{~mm}$ Hepes/ $\mathrm{NaOH}$ ). Concentrations of $\mathrm{Ca}$ and glucose were altered between 2.4 and 19.2 and between 2.7 and $50 \mathrm{~mm}$, respectively. For Nafree medium, $\mathrm{Na}$ was totally replaced by choline. Glass micropipettes filled with $4 \mathrm{M} \mathrm{K}$-acetate were used for membrane potential recording and the electrode resistance was between 80 and $440 \mathrm{M} \Omega$. Depolarizing or hyperpolarizing current was supplied by a preamplifier (ME Commercial AM-1) and injected through the recording micropipettes. Intracellular potential was displayed on a storage oscilloscope (Tektronix R5113N) and photographed.

$\mathrm{A}$ and $\mathrm{B}$ cells were identified in the monolayer culture of the neonatal rat pancreas under a phase contrast inverted microscope (Olympus IM) according to the following criteria (KANAZAWA et al., 1976), as shown in Fig. 1A. Namely, the most frequently encountered cells characterized by relatively large size, round shape and light cytoplasm were recognized as B cells. Less frequently encountered cells having the characteristics of relatively small size, oval or spindle shape and dark cytoplasm were identified as A cells (Fig. 1). The other unidentified endocrine cells in the culture were not tested for intracellular recording.

Four morphologically identified A cells were successfully impaled. As shown in Fig. 2A, the identified A cells produced action potentials at the break of the hyperpolarizing pulse (Aa) or during the depolarizing pulse in an all-ornone fashion $(\mathrm{Ab})$. In addition, the $\mathrm{A}$ cell was found to generate an action potential in the Na-free medium (Fig. 2Ac). As indicated in these records, the evoked action potentials were of single spike type and never showed a depolarizing plateau phase. The excitability in these culture cells was maintained for no longer than about $1 \mathrm{~min}$ and usually, extreme increases in both membrane conductance and resting membrane potential ensued.

In order to determine whether the spike action potential may be characteristic of A cells, we further investigated 29 morphologically identified B cells for electrical excitability. These $\mathrm{B}$ cells also generated the monophasic spike action potential at the break of the hyperpolarizing pulse or during the depolarizing pulse in an all-or-none fashion (Fig. 2Ba, b). No depolarizing plateau phase was observed. In the Na-free solution, the $\mathrm{B}$ cells also produced a single spike action potential (Fig. 2Bc). Spontaneously occurring action potentials which were very rarely observed were also of the single spike-type as shown in Fig. 2Bd (hollow triangle mark).

The spike action potentials observed in the above experiments may reflect a possible immaturity in membrane properties of pancreatic endocrine cells originating from neonatal rats. Thus, we prepared a cell culture of the adult rat pancreas and tested them for intracellular recording. Each of the cultured endocrine cells from the adult rat pancreas was spherical in shape and isolated completely from other cells as shown in Fig. 1B. However, the cell type could not be identified, since external appearances were similar. Fifteen of these adult cells were successfully impaled and found to produce action potentials in response to the in- 


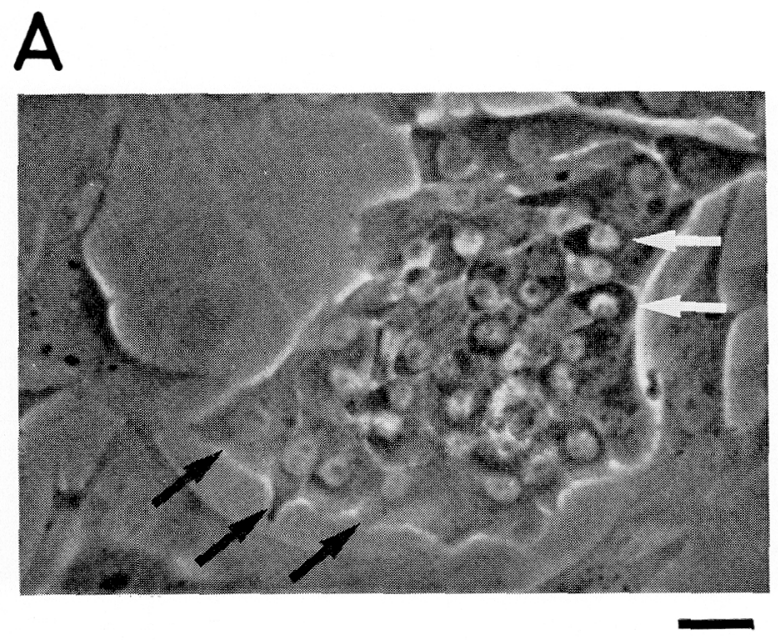

\section{B}

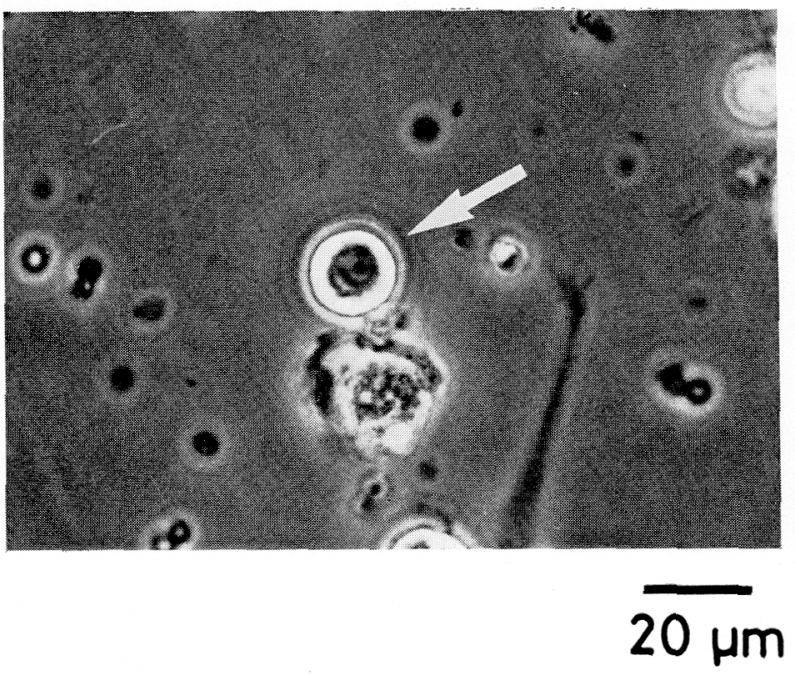

Fig. 1. Pancreatic endocrine cells in monolayer culture derived from neonatal (A) and adult (B) rats. In A, black and white arrows indicate morphologically identified A and B cells, respectively. The photograph represents an example of exceptionally numerous A cells in a single visual field; the number of A cells in a visual field was usually one or two at most. In $\mathbf{B}$, a white arrow indicates an endocrine cell. Note that the cell is completely isolated from other cells. Both photographs were taken under a phase contrast microscope. 

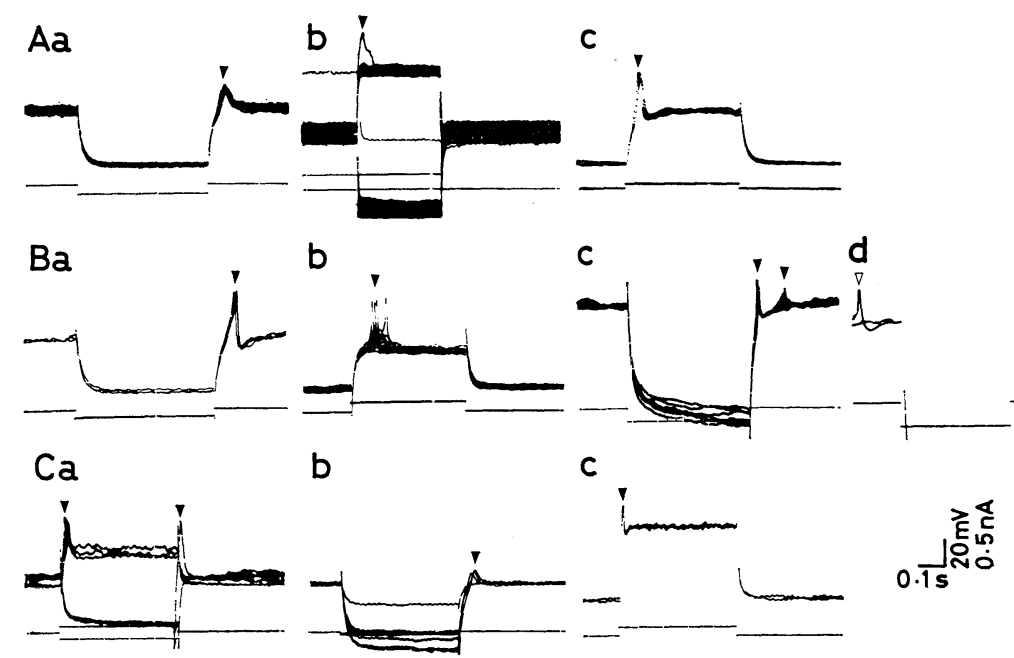

Fig. 2. Action potentials recorded from pancreatic endocrine cells. Solid and hollow triangle marks indicate evoked and spontaneously occurring action potentials, respectively. A: records taken from the A cells of neonatal rat origin identified morphologically. Alterations of constituents of the medium were $1.7 \mathrm{~mm}$ glucose in $\mathrm{Ab}$ and Na-removal in Ac. B: records taken from identified B cells of neonatal rat origin. Changes in the medium were $5 \mathrm{~mm} \mathrm{Ca}$ in a, $7.2 \mathrm{~mm} \mathrm{Ca}$ and $50 \mathrm{~mm}$ glucose in $\mathrm{b}$, Naremoval in c, and $4.8 \mathrm{~mm} \mathrm{Ca}$ and $16.7 \mathrm{~mm}$ glucose in $\mathrm{d}$. Note that the spontaneously occurring action potential (hollow triangle mark in d) is of the simple spike-type. C: records taken from cultured cells of the adult rat pancreas. In a, both depolarizing and hyperpolarizing pulses were effective for evoking action potentials in this cell. Changes in the medium were $19.2 \mathrm{~mm} \mathrm{Ca}$ in a, and Na-removal and $19.2 \mathrm{~mm} \mathrm{Ca}$ in b and c. It is noted that action potentials were evoked by injected current in an all-or-none fashion.

jected current (Fig. 2C). The action potentials evoked in the adult cells were of the simple spike type and quite similar to those observed in the cultured cells derived from neonatal rats. The electrical excitability was found to exist also in the Na-free medium (Fig. 2Cb, c).

The present experiments clearly demonstrated for the first time that A cells identified morphologically in the monolayer culture generate an action potential in response to the injected current. The pancreatic endocrine cells in monolayer culture with the morphological characteristics which were used in the present study as the criteria for identification of A cells have been shown to contain immunoreactive glucagon (KANAZAWA et al., 1976) and to secrete the hormone in response to various stimuli (OrCI et al., 1973; MARLiss et al., 1973). It is thus concluded that A cells in the pancreatic islet can generate action potentials.

It is well established that B cells in the isolated mouse pancreatic islet generate a burst-discharge of spikes superposed on a depolarization plateau in response to glucose in the medium. Recently it has been further demonstrated that the 
depolarizing plateau potential can be induced in a voltage-dependent manner in B cells of the isolated mouse islet (CoOK et al., 1980). However, in the present experiments with monolayer culture of the rat pancreas, the action potentials evoked in the identified A cells of the neonatal rat origin were of the simple spike type. The spike action potential is characteristic not only of A cells but also of B cells and adult islet cells in culture. Thus it is likely that endocrine pancreas cells in culture cannot generate the depolarizing plateau potential.

In the present experiments morphologically identified A and B cells were both capable of producing action potentials in the Na-free medium. B cells in the isolated mouse islet have been demonstrated to generate $\mathrm{Ca}$-dependent action potentials (DeAN and MatThews, 1970; MeisSner and Schmelz, 1974; MATthews and SAKамото, 1975). Therefore, it is very likely that the action potential produced in the pancreatic A cell is also a Ca spike. In addition to the pancreatic B cell (DEAN and MatTHEws, 1968), a variety of endocrine cells such as anterior pituitary cells (OzAWA and SAND, 1978) and adrenal chromaffin cells (BIALES et al., 1976; BRANDT et al., 1976), and hormone-secreting tumour cells such as medullary thyroid carcinoma cells (TISCHLER et al., 1976), anterior pituitary tumour cells (KiDOKORO, 1975; BiAles et al., 1977) and pheochromocytoma cell line PC12 (DiCHTER et al., 1977), have been demonstrated to generate action potentials which are dependent on external $\mathrm{Ca}$ or on both $\mathrm{Ca}$ and $\mathrm{Na}$. The present results provide an additional clue to the concept that endocrine cells produce an action potential which is at least in part dependent on external $\mathrm{Ca}$.

We thank Drs. Y. Kanazawa, S. Ozawa, and S. Miyazaki for their technical suggestions and help. This work was supported by the Grant No. 56770058 from the Ministry of Education, Science and Culture, Japan.

\section{REFERENCES}

Biales, B., Dichter, M., and Tischler, A. (1976) Electrical excitability of cultured adrenal chromaffin cells. J. Physiol. (Lond.), 262: 743-753.

Biales, B., Dichter, M. A., and Tischler, A. (1977) Sodium and calcium action potential in pituitary cells. Nature, 267: 172-174.

Brandt, B. L., Hagiwara, S., Kidokoro, Y., and MiYazaki, S. (1976) Action potentials in the rat chromaffin cell and effects of acetylcholine. J. Physiol. (Lond.), 263: 417-439.

CoOK, D. L., CrILl, W. E., and Porte, D., Jr. (1980) Plateau potentials in pancreatic islet cells are voltage-dependent action potentials. Nature, 286: 404-406.

Dean, P. M. and MatThews, E. K. (1968) Electrical activity in pancreatic islet cells. Nature, 219: 389-390.

DeAn, P. M. and MatThews, E. K. (1970) Electrical activity in pancreatic islet cells: Effect of ions. J. Physiol. (Lond.), 210: 265-275.

Dichter, M. A., Tischler, A. S., and Greene, L. A. (1977) Nerve growth factor-induced increase in electrical excitability and acetylcholine sensitivity of a rat pheochromocytoma cell line. Nature, 268: 501-504.

Kanazawa, Y., Ikeuchi, M., Kawazu, S., Ito, S., and Kosaka, K. (1976) Dynamic cytology of pancreatic cells in monolayer culture. In: Diabetes, ed. by BAJAJ, J. S. Excerpts Medica,

Vol. 32, No. 5, 1982 
Amsterdam and Oxford, pp. 502-507.

Kawazu, S., Kanazawa, Y., IKeuchi, M., Hayashi, M., and KosaKa, K. (1977) The dynamic of insulin release from monolayer-cultured pancreatic cells in a new perifusion system. Proc. Soc. Exp. Biol. Med., 156: 197-200.

Kidokoro, Y. (1975) Spontaneous calcium action potentials in a clonal pituitary cell line and their relationship to prolactin secretion. Nature, 258: 741-742.

Lambert, A. E., Blondel, B., Kanazawa, Y., OrCI, L., and Renold, A. E. (1972) Monolayer cell culture of neonatal rat pancreas: Light microscopy and evidence for immunoreactive insulin synthesis and release. Endocrinology, 90: 239-248.

Marliss, E. B., Wollheim, C. B., Blondel, B., Orci, L., Lambert, A. E., Stauffacher, W., LIKE, A. A., and Renold, A. E. (1973) Insulin and glucagon release from monolayer cell cultures of pancreas from newborn rats. Eur. J. Clin. Invest., 3: 16-26.

Matthews, E. K. and SAKamoto, Y. (1975) Electrical characteristics of pancreatic islet cells. J. Physiol. (Lond.), 246: 421-437.

MeIsSner, H. P. and Schmelz, H. (1974) Membrane potential of beta-cells in pancreatic islets. Pflügers Arch., 351: 195-206.

Orci, L., Like, A. A., Amherdt, M., Blondel, B., Kanazawa, Y., Marliss, E. B., Lambert, A. E., Wollheim, C. B., and Renold, A. E. (1973) Monolayer cell culture of neonatal rat pancreas: An ultrastructural and biochemical study of functioning endocrine cells. $J$. Ultrastruct. Res., 43: 270-297.

OzawA, S. and SAND, O. (1978) Electrical activity of rat anterior pituitary cells in vitro. Acta Physiol. Scand., 102: 330-341.

Tischler, A. S., Dichter, M. A., Biales, B., Delellis, R. A., and Wolfe, H. (1976) Neural properties of cultured human endocrine tumor cells of proposed neural crest origin. Science, 192: 902-904. 